\title{
石炭急速水添ガス化プロセス
}

\author{
（キーワード＼cjkstart水添ガス化、ガス化プロセス） \\ - 1990.6.21 受理一
}

東京ガス株式会社 高 橋

容

1. はじめに

水添ガス化法は, 効率良くメタン等の高力ロ リーガスを製造することができ, さらに, 付加 価值の高い芳香族油の併産が可能なガス化法で ある。この水添ガス化法に関しては,これまで にいくつかのガス化プロセスが提案されている が，未だ実用化には至っておらず，多くの技術 的課題を解決しなければならない。

近年, 米国 Rockwell International 社により 開発された石炭急速水添ガス化法は，プロセス の実用化を考える上で最も有望な技術のひとつ である。この石炭急速水添ガス化法は Rockwell International 社がスペースシャトル等液体 ロケットエンジン関連技術を石炭ガス化技術に 応用して開発したものであり，この技術に関連 して国際共同開発プログラムが行われ，日本か らも新エネルギー総合開発機構 (NEDO) およ び民間企業 6 社よりなるグループが同プログラ ムに参加した。

ここでは, Rockwell International 社で開発さ れた技術を中心に, 石炭急速水添ガス化プロセ スについて紹介する。

\section{2. 石炭急速水添ガス化技術}

急速水添ガス化法は米国の Rockwell International 社で開発された石炭のガス化法であり, 石炭を単段反応器中短時間で高温・高速水素と 反応させ主製品としてメタン, 副生品としてべ ンゼンまたは芳香族油を生産する技術である。

技術研究所 東京都港区芝浦 $1-16-25$
本ガス化法は特に，ロケットエンジン関連技 術を応用して開発されたガス化反応器に特徴が ある。急速水添ガス化反応器の概念図を図 1 に 示す。反応器は単段の噴流層タイプであり, 最 上部のインジェクターより微粉炭および高温・ 高速の水素が供給される。微粉炭は石炭フィー ダーから濃厚相輸送により反応器内に噴霧され る。一方, 水素はインジェクター内の燃焼室で 微量の酸素により部分燃焼し温度約 $1,300^{\circ} \mathrm{C} に$ 昇温され反応器内に噴射される。微粉炭と高 温・高速の水素ガスは瞬間的に混合して反応開 始温度に達し水添ガス化反応が進行する。滞留 時間は短く最大 10 秒であり, 反応温度は反応器

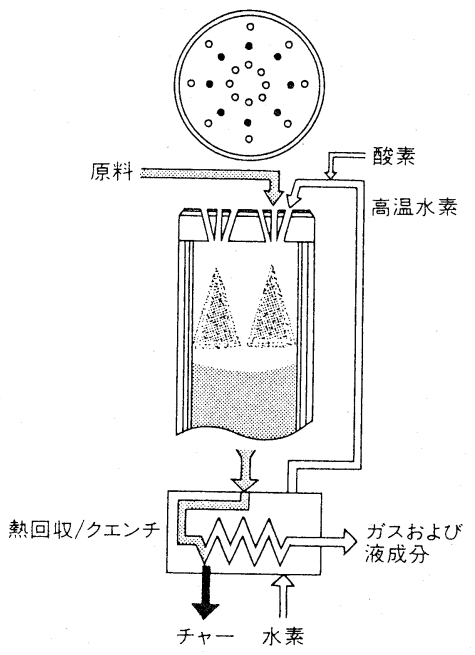

図 1 石炭急速水添ガス化反応器概念図 ${ }^{1)}$ 
出口で, メタンのみ生産の場合 $900 \sim 1,000^{\circ} \mathrm{C}$, メタン/ベンゼン併産の場合最低 $600^{\circ} \mathrm{C}$ であ。

急速水添ガス化反応器の特長としては, イン ジェクター内に導入する酸素量の調整により反 応温度の制御が容易であり, 反応温度や滞留時 間等の反応条件を変えることによりメタンと芳 香族油の生成比率をコントロールすることがで きる。他の特長として, 反応器がコンパクトで ある, スタートアップが迅速容易である，炭種 適応性が高い，等がある。

\section{3. 急速石炭水添ガス化テスト}

Rockwell International 社で開発された石炭急 速水添ガス化反応器の性能評価, 商業規模プラ ントの設計，およびプロセスの経済性評価を目 的としたプロセス開発用プラント (Process Development Unit）によるガス化テストが国際共 同開発プログラム（1984年 1 月〜 1986年 2 月） により行われた。この国際共同開発プログラム には，日本から NEDO および民間企業グルー プ (大阪ガス, 新日本製鉄, 東京ガス, 東邦ガ ス, 三菱重工業, 三菱商事) が参加した。

国際共同開発プログラムにおけるガス化テス 卜は最大石炭処理量 $1 \mathrm{t} / \mathrm{h}$ のプロセス開発用 プラントにより原料石炭として米国瀝青炭のケ ンタッキーNo.9を使用し, 滞留時間, 反応器 出口温度, ガス/石炭比等を変化させガス化 デー夕を取得した。ガス化データの一例を表 1 に示す ${ }^{1)}$ 。最近では, ベンチプラント規模の Rockwell夕イプの急速水添ガス化反応器による 水添ガス化反応に関する基礎研究も実施されて いる。

表 1 に示すように急速水添ガス化反応器では 反応条件を変化させることにより炭化水素ガス としてメタンのみを生産させること, あるいは メタンとベンゼンを併産させることができるこ とがわかる。実験結果に基づく反応シミュレー ションの結果によれば, 適当な反応温度および 滞留時間を選択すれば液成分として重質分なし でベンゼンのみを生成させることも可能である。 また, 石炭中の炭素がチャー以外の生成物に移 行した割合を示す全炭素転化率が極めて高い。 これは, 高温・高速水素により石炭を急速昇温
表 1 石炭急速水添ガス化テストデータ例1)

\begin{tabular}{|c|c|c|}
\hline & 例 1 & 例 2 \\
\hline 原料石炭 & $\begin{array}{l}\text { ケンタッキー } \\
\text { No. } 9\end{array}$ & $\begin{array}{l}\text { ケンタッキー } \\
\text { No. } 9\end{array}$ \\
\hline 反応器出口温度 $\left({ }^{\circ} \mathrm{C}\right)$ & 1092 & 988 \\
\hline 滞留時間 $(\mathrm{sec})$ & 6.1 & 2.3 \\
\hline 反応压力 $\left(\mathrm{kg} / \mathrm{cm}^{2} \mathrm{G}\right)$ & 68 & 68 \\
\hline ガス/石炭比 (kg-mol/kg) & 0.25 & 0.19 \\
\hline スチーム濃度(mol\%) & 43.5 & 28.6 \\
\hline \multicolumn{3}{|l|}{ ガス化生成物(炭素転化率(\%)) } \\
\hline $\mathrm{CH}_{4}$ & 39.0 & 33.6 \\
\hline $\mathrm{C}_{2} \mathrm{H}_{6}$ & 0.03 & 0.15 \\
\hline $\mathrm{C}_{6} \mathrm{H}_{6}$ & 0 & 9.8 \\
\hline $\mathrm{C}_{7} \mathrm{H}_{8}$ & 0 & 0.07 \\
\hline $\mathrm{CO}$ & 22.2 & 3.4 \\
\hline $\mathrm{CO}_{2}$ & 7.2 & 0.8 \\
\hline 非 BTX 液成分 & 0 & 7.58 \\
\hline 計 & 68.4 & 55.4 \\
\hline
\end{tabular}

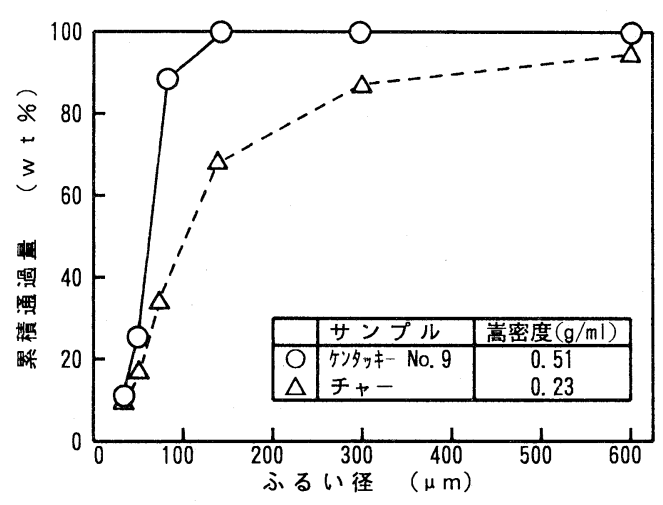

図 2 チャー, 石炭のふるい分析および嵩密度 ${ }^{2)}$

させたためと考えられる。このように，急速水 添ガス化法では, 短時間の内に効率良く石炭を 有用物質に転換することができ，生成物分布の 制御が容易であることが示された。

急速水添ガス化生成物のひとつであるチャー は急激な昇温過程を経ることにより粒径が成長 することが報告されている ${ }^{2)}$ 。急速水添ガス化 反応後のチャーと原料石炭のふるい分析結果お よび嵩密度の比較を図 2 に示す。図 2 より反応 後のチャーは急激な揮発分の発生により粒径が 成長し多孔質となっており, 活性なチャーとし て原料水素の製造等への利用が可能であること 


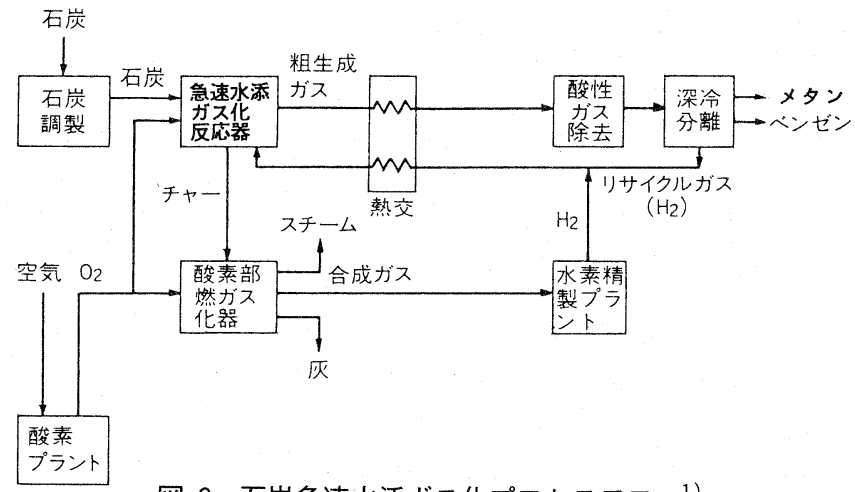

図 3 石炭急速水添ガス化プロセスフロー1)

も急速水添ガス化法の特長である。

\section{4. 急速石炭水添ガス化プロセス}

急速水添ガス化反応器を中心とするメタン／ ベンゼン併産プラントのプロセスフローは図 3 に示すようなものが考えられている1)。石炭急 速水添ガス化プロセスの主要構成要素は次の通 りである。

(1) 急速水添ガス化反応器

(2) 生成ガスの冷却／熱回収器

(3) 酸性ガス除去装置

(4) メタンおよびベンゼンとリサイクル水素 の深冷分離装置

(5) 部分燃焼ガス化反応器

メタンのみを生産する場合，高温の条件下に おいて反応器内でメタンおよび一酸化炭素等が 生成し，ベンゼン等の液成分は残存しない。廃 熱回収後, 選択的レクチゾール法により酸性ガ ス除去が行われる。メタンは深冷分離によりリ サイクル水素と分離される。硫黄およびアンモ ニアは副生物として回収され，水添ガス化反応 器で生成するチャーは部分燃焼ガス化反応器に おいて原料水素ガスの製造に使用される。

メタン/ベンゼン併産プロセスの場合，生成 したメタンおよびベンゼンは熱回収後, 酸性ガ ス除去を経て樑冷分離で分離される。

図 3 に示したプロセスフローは急速水添ガス 化プロセスの一例であるが，プロセスの総合熱 効率は約 $74 \%$ と報告されており ${ }^{1)}$ ，酸素部分燃
焼法による合成ガス経由のメタン製造プロセス (総合熱効率は $62 \sim 66 \%{ }^{3)}$ ) と比較しても優れ たプロセスであると言える。

\section{5. おわりに}

石炭の急速水添ガス化法は， ロケットエンジ ン技術の応用により開発された特色ある技術で あり，将来の石炭ガス化技術に重要な役割を果 たすものと考えられる。また, 石炭の水添ガス 化は, 将来の石炭利用拡大に備え, 現在より継 続的に取り組むべき技術開発課題であり，まず， 基礎から応用に至るまで幅広く石炭水添ガス化 を理解することが必要である。

本稿は Rockwell International 社を中心とす る研究成果に基づき書かれたものである。ここ に, Rockwell International 社ならびに石炭急速 水添ガス化に関する国際共同開発プログラムに 参加したNEDOをはじめとする日本グループ 各社の方々に感謝致します。

\section{文献}

1 ) 正田知士, 石炭化学工学 (化学工業社), p.134 (1986)

2 ) Falk, A. K., Schuman, M. D. and Kahn, D. R., DOE Research and Development Report, ET-10328-49 (1986)

3 ) Grainger, L. and Gibson, J., Coal Utilisation: Technology, Economics \& Policy, (Graham and Trotman) p.345 (1981) 


\title{
Flash Hydrogasification Process
}

\author{
Iruru TAKAHASHI
}

(Research and Development Institute, Tokyo Gas Co., Ltd.)

\begin{abstract}
SYNOPSIS : - A flash hydrogasification is of particular interest because it produces methane in a single stage reaction with high efficiency and simultaneously produces aromatic liquids as by-products. This paper describes the flash hydrogasification process proposed by Rockwell International Corporation. The flash hydrogasifier was developed by the application of Rockwell's rocket engine technologies. Using the hydrogasifier, a pulverized coal can be readily gasified with high temperature hydrogen jets to produce methane and benzene. A number of gasification tests were carried out to investigate the hydrogasifier performance in the Advancement of Flash Hydrogasification Program by Rockwell International and the industrial consortium. On the basis of the results, the thermal efficiency of the flash hydrogasification process was estimated at $74 \%$.

The flash hydrogasification will be the key technology and take an important role in the utilization of coal in the future.
\end{abstract}

\section{Key Words}

Hydrogasification, Gasification process

\section{書 評}

\section{Current and Prospective Australian Coal Supply}

$$
\left(\begin{array}{c}
\text { Eric D. Jamieson 著 } \\
\text { IEA Coal Research } 1990.2 \text {. }(\text { 定価 £85.00) }
\end{array}\right)
$$

本書は, 表題のとおり世界第 7 位の瀝青炭の産出国であ るオーストラリアの石炭供給力の現状と将来についてまと められたものである。

目次を追って紹介すると，

第 I 章は導入部で背景が述べられ，国際規模でのオース トラリアの石炭供給の位置付けと国内のエネルギー・・経済 発展に対する石炭の重要性について議論が展開する。

第 II 章は豪州炭の現在の位置付けについて，まず豪州に おける最近の石炭消費, 供給および輸出についての考察, 豪州の現在の石炭供給力に関する基本的考察（地質, 採掘 方法, 生産コスト, 生産性, 環境問題, 輸送拈よびインフ ラストラクチャー), 豪州石炭産業の発展と構造およびそ の実績, 連邦および州政府の石炭政策等, 豪州炭の現在の
供給価格, そして要約として豪州の石炭 (瀝青炭) の供給 能力, 以上の 6 項目が詳述される。

第吕章は豪州石炭の将来について, 豪州炭の需要予測, 豪州炭の供給予測, 予測される需要／供給の調整（コスト 予測と供給能力予測）が議論される。

結論として2005年時点の生産量を, 治金用コークス用炭 および発電用炭合計して 200 百万 $\mathrm{t} /$ 年に達するものと予 測している。(125百万 $\mathrm{t} /$ 年, 1987-88年)

豊富な統計デー夕を用いてまとめられた本書は, 世界の 石炭エネルギー需給において重要な位置を占める豪州炭の みならず広く石炭に携わっておられる方には是非ご一読を お奨めしたい。

（越後 格之） 